\title{
Analisis pola argumentasi siswa dalam menyelesaikan soal permutasi dan kombinasi
}

Hasanul Anshori ${ }^{1}$, Parhaini Andriani ${ }^{2}$

* Affiliasi: Universitas Islam Negeri Mataram

\section{Keywords: \\ Patterns of \\ argumentation, problem \\ solving, permutations and combinations}

\section{Kata Kunci:}

Pola argumentasi,

Pemecahan masalah, permutasi dan kombinasi

\begin{abstract}
A b s t r a c t: Argumentation is a person's way to face every question, issue and argue in the face of every problem. Argumentation is very necessary to know the understanding of students' concepts and so that students can explain logically the appropriate stages of completion to solve problems. This study aims to describe the pattern of argumentation used by students in solving permutations and combinations problems. This type of research is descriptive qualitative. The research subjects were 3 students of class XI IPA at MA Darul Aitam Jerowaru which consisted of 1 student with high math ability, 1 student with moderate math ability, and 1 student with low math ability. Sampling was done by using purposive sampling type quota sampling. Data collection techniques used written tests and interviews, then analyzed based on indicators of student argumentation patterns in solving permutations and combinations. Based on this, the argumentation pattern used in this study is a combination of Tulmin's argumentation pattern and Mc. Neill \& Karajicik's argumentation pattern, namely, data, claim, evidence, reasoning and rebuttal. The results of this study are students with high mathematical abilities have a pattern of argumentation, namely, data, claims, evidence, which are given correctly. Students with moderate ability have argumentation patterns, namely, data, claim, reasoning, and rebuttal, which are given correctly and students with low mathematical abilities have argumentation patterns, namely, data, claim, and rebuttal, which are given correctly.
\end{abstract}

\begin{abstract}
A b s t r a k: Argumentasi merupakan cara seseorang untuk menghadapi setiap pertanyaan, isu-isu serta membantah dalam menghadapi setiap masalah. Argumentasi sangat diperlukan untuk mengetahui pemahaman konsep siswa dan agar siswa dapat menjelaskan secara logis tahapan penyelesaian yang tepat untuk menyelesaikan masalah. Penelitian ini bertujuan untuk mendeskripsikan pola argumentasi yang digunakan siswa dalam menyelesaikan soal permutasi dan kombinasi. Jenis penelitian ini adalah deskriptif kualitatif. Subyek penelitian adalah 3 siswa kelas XI IPA di MA Darul Aitam Jerowaru yang terdiri dari 1 siswa berkemampuan matematika tinggi, 1 siswa yang berkemampuan
\end{abstract}

\footnotetext{
${ }^{1}$ E-mail addresses: hasanulanshori7@gmail.com

${ }^{2}$ Coresponden to author: Fakultas Tarbiyah dan Keguruan, Universitas Islam Negeri Mataram, Jl. Gajah Mada Jempong, Indonesia. (83116), E-mail addresses: parbaini.andriani@uinmataram.ac.id
} 
matematika sedang, dan 1 siswa yang berkemampuan matematika rendah. Pengambilan sampel dilakukan dengan menggunakan purposive sampling jenis quota sampling. Teknik pengumpulan data menggunakan tes tertulis dan wawancara, kemudian dianalisis berdasarkan indikator pola argumentasi siswa dalam menyelesaikan soal permutasi dan kombinasi. Berdasarkan hal tersebut, maka pola argumentasi yang digunakan dalam penelitian ini adalah gabungan kemampuan matematika tinggi memiliki pola argumentasi yaitu, data, claim, evidence, yang diberikan dengan tepat. Siswa berkemampuan sedang memiliki pola argumentasi yaitu, data, claim, reasoning, dan rebuttal, yang diberikan dengan tepat dan juga siswa dengan kemampuan matematika rendah memiliki pola argumentasi yaitu, data, claim, dan rebuttal, yang diberikan dengan tepat.

\section{Article info}

Article History: Received 20 Agustus 2021 | Revised 30 Agustus 2021| Accepted 16 September 2021 | Available online 20 September 2021

\section{Pendahuluan}

Belajar adalah suatu proses usaha yang dilakukan seseorang untuk memperoleh suatu perubahan tingkah laku yang baru secara keseluruhan, sebagai hasil pengalamanya sendiri dalam interaksi dengan lingkunganya. Menurut pendapat dari Mustaqim belajar adalah perubahan tingkah laku yang relatif tetap yang terjadi latihan dan pengalaman dengan kata lain yaitu suatu aktifitas atau usaha yang disengaja aktifitas tersebut menghasilkan perubahan, berupa sesuatu yang baru baik yang segera nampak atau tersembunyi tetapi juga hanya berupa penyempurnaan terhadap sesuatu yang pernah dipelajari. Dari beberapa pendapat ahli di atas dapat disimpulkan bahwa belajar adalah perilaku yang dilakukan oleh individu untuk meperoleh pengetahuan baru dengan cara latihan dan pengalamannya sendiri setelah interaksi dengan lingkungan disekitarnya. Belajar dapat memberikan pengetahuan baru, menumbuhkan sikap kritis siswa terhadap semua yang mereka pelajari. Sama halnya dengan pembelajaran matematika.

Menurut hasil Trendes in Mathematics and Science study (TIMMS) pada tahun 2019, yang diikuti oleh 49 Negara, menempatkan prestasi siswa Indonesia dalam bidang matematika berada dalam urutan ke 44, dengan skor rata- rata 397(skor rata-rata Internasional $=500$ ), sehingga ini membuktikan bahwa kemampuan matematika siswa Indonesia sangat kurang dibandingkan dengan Negara lain. Pada dasarnya untuk meningkatkan kemampuan matematika siswa Indonesia perlu dilakukan perbaikan dalam proses pembelajarannya. Untuk itu dalam pembelajaran matematika siswa tidak hanya diajarkan untuk menyelesaikan soal saja tetapi mereka diajarkan untuk berargumentasi. Menurut Hartiana bahwa kemampuan yang harus dipelajari dan dikuasai oleh para siswa selama proses pembelajaran matematika di kelas salah satunya adalah berargumentasi secara matematis, dalam hal ini mencakup memahami pembuktian, mengetahui bagaimana membuktikan, mengikuti dan menilai rangkaian argumentasi, memiliki kemampuan menggunakan setrategi, dan menyusun argumentasi. Guru memiliki peran dalam memberdayakan siswa untuk membenarkan suatu pernyataan matematiks 
yang dapat mempengaruhi kemampuan berargumentasi siswa. Argumentasi menujukkan kemampuan mengemukakan alasan secara logis yang disertai data dan dukungan teori yang memadai baik dalam bentuk lisan maupun tulisan. Menurut Fadillah argumentasi berkaitan dengan kemampuan komunikasi seseorang untuk memberikan alasan yang berbasis pada faktafakta untuk membuat kesimpulan dan seiring digunakan dalam bukti matematika. Menurut Laamena argumentasi tidak dapat dikatakan benar atau salah tetapi sah atau tidak, sehingga kemampuan seseorang tidak menjamin keabsahan suatu argumentasi.

Dalam matematika, argumentasi sangat diperlukan untuk pemahaman konsep siswa dan agar siswa dapat menjelaskan secara logis dan memutuskan cara atau penyelesaian yang tepat untuk menyelesaikan masalahnya. Kemampuan argumentasi sangat erat kaitannya dengan kemampuan penalaran, karena tanpa kemenpuan penalaran maka siswa tidak dapat membangun kemampuan berargumentasi. Pada penyelesaian soal matematika siswa di tuntut untuk merumuskan masalah, memilih strategi yang tepat, mengunakan argumen-argumen mengenai kebenaran dari solusi yang ia berikan dalam penyelesaian soal.

Ada beberapa pola argumentasi siswa yang dapat digunakan untuk megidentifikasi pola argumentasi siswa, yaitu pola argumentasi Mc. Neill \& Krajicik dan pola argumentasi Toulmin. Pola argumentasi Mc. Neill \& Krajicik terdiri dari 3 aspek yaitu, (1) claim: siswa mampu menyatakan langkah mana yang benar dan langkah mana yang salah, (2) evidence: siswa mampu menujukan data yang mampu mendukung pernyataan yang dikemukakan, (3) reasoning: siswa mampu memberikan alasan sebagai pembenaran dari pernyataan yang disertai dengan bukti. Sedangkan pola argumentasi Toulmin memiliki 6 aspek yaitu, (1) data: siswa mampu mengidentifikasi informasi dan mampu menyatakan informasi apa saja yang ada pada tiap langkah penyelesaian, (2) claim: siswa mampu menyatakan langkah mana yang benar dan langkah mana yang salah, (3) warrant: siswa mampu memberikan alasan mengenai claim yang di keluarkan siswa, (4) backing: siswa mampu memberikan bukti untuk mendukung warrant, (5) qualifier: siswa mampu menujukan tingkat keyakinan akan claim yang diberikan, (6) rebuttal: siswa mampu menolak pernyataan dan menjelaskan kondisi di mana pernyataan tersebut tidak berlaku .

Argumentasi sering dikaitkan dengan penalaran dan proses berpikir. Menurut pendapat Seokisno bahwa argumentasi merupakan fondasi untuk mengemukakan suatu alasan (berpikir kritis) disertai dengan data dan dukungan teori yang memadai dari suatu masalah matematika (berpikir logis). Terutama pada materi permutasi dan kombinasi. Permutasi dan kombinasi sering berkaitan dengan materi yang berhubungan dengan soal cerita, sehingga dari soal cerita ini akan ditentukan peluang suatu kejadian. Menurut pendapat Wirodikromo bahwa permutasi dan kombinasi merupakan kaidah pemecahan yang dibutuhkan dalam menyelesaikan peluang suatu kejadian. Pada materi permutasi dan kombinasi siswa dituntut untuk memiliki kemampuan dalam berargumentasi, sehingga dapat membantu siswa dalam menyelesaikan atau memecahkan masalah dengan menggunakan penalaran. Maka penting bagi guru untuk melatih kemampuan argumentasi siswa salah satunya kemampuan argumentasi pada materi permutasi dan kombinasi. 
Berdasarkan hasil observasi pada tanggal 15 Oktober 2020 di sekolah Madrasah Aliyah Darul Aitam Jerowaru kelas XI IPA bahwa pada saat diberikan soal matematika siswa dapat mengerjakan dengan benar, tetapi pada saat mereka diminta untuk menjelaskan dari setiap proses penyelesaian soal yang mereka selesaikan mereka memperoleh kesulitan. Berdasarkan uraian diatas tersebut maka, fokus penelitian adalah untuk mengetahui pola argumentasi yang digunakan siswa dalam menyelesaikan soal permutasi dan kombinasi.

Pada penelitian ini juga akan mengunakan gabungan dari pola argumentasi Tulmin dan pola argumentasi Mc.Neill \& Karajicik. Indikator dari gabungan dua pola argumentasi tersebut adalah (1) Data, yakni siswa mampu mengidentifikasi informasi dan mampu menyatakan informasi apa saja yang ada pada soal dan pada tiap langkah penyelesaian. (2) Claim, yakni siswa mampu memberikan pernyataan untuk menjawab permasalahan yang diberikan. (3) Evidence, yakni siswa mampu menunjukan data yang mampu mendukung pernyataan yang dikemukakan. (4) Reasoning, yakni siswa mampu memberikan alasan sebagai pembenaran dari pernyataan yang disertai dengan bukti. (5) Rebuttal, yakni siswa mampu menolak pernyataan dan menjelaskan kondisi di mana pernyataan tersebut tidak berlaku. Sehingga penelitian ini layak untuk diteliti.

\section{Metode}

Jenis penelitian yang digunakan adalah deskriptif Kualitatif untuk mengambarkan pola argumentasi siswa dalam menyelesaikan soal permutasi dan kombinasi. Subjek penelitian ini adalah siswa kelas XI IPA Madrasah Darul Aitam Jerowaru. Siawa yang menjadi subjek penelitian berjumlah 3 siswa dari 20 siswa kelas XI IPA. Pemilihan 3 siswa didasarkan dengan tingkat kemampuan matematika (tingkat kemampuan rendah, tingkat kemampuan sedang, dan tingkat kemampuan tinggi). Dalam penelitian ini, peneliti merupakan istrumen utama dan dibantu dengan beberapa instrument lainya. Istrumen pendukung yang digunakan dalam pengumpulan data terdiri dari dua sial tes dan juga pedoman wawancara. Kedua instrument pendukung tersebut telah melalui validasi ahli yang berjumlah dua orang. Dalam pengumpulan data, menggunakan soal tes dan wawancara. Soal tes yang diberikan berbentuk soal cerita dan soal benar salah. Hal ini bertujuan untuk mengetahui pola argumentasi yang siswa berikan untuk soal cerita sampai dengan soal benar salah. Wawancara digunakan untuk mengonfirmasi hasil pekerjaan siswa pada kedua tes yang telah diberikan. Teknik analisis data pada penelitian ini yaitu dengan mengkoding argumentasi siswa pada transkrip hasil wawancara yang sesuai dengan indikator pola argumentasi yang tercantum pada tabel. Data-data yang telah didapatkan kemudian dikelompokkan dan dituliskan dalam bentuk teks yang bersifat naratif.

\section{Hasil dan Pembahasan}

Rancangan Soal

Soal yang diberikan terdiri dari 2 soal, yaitu soal nomor 1 adalah soal cerita yang sering siswa jumpai seperti yang terlihat pada Gambar 1. 


\section{Gambar 1. Soal Cerita Permutasi}

Di kelas Alvian dan Fina dilakukan pemilihan ketua kelas, wakil ketua, sekretaris dan bendahara dari 6 siswa yang tersedia. Alvian dan Fina diminta untuk menghitung banyak cara memilih ketua, wakil ketua, sekretaris dan bendahara di kelasnya tersebut. Berikut hasil kerja mereka.

a. Hasil kerja Alvian

${ }_{6} \mathrm{P}_{4}=\frac{6 !}{(6-4) !}=\frac{6 !}{2 !}=\frac{6 \times 5 \times 4 \times 3 \times 2 \times 1}{2 \times 1}=\frac{720}{2}=360 \mathrm{Cara}$

Apakah langkah-langkah pekerjaan yang dilakukan Alvian benar? Berikan alasan.

b. Hasil kerja Fina

${ }_{6} \mathrm{P}_{4}=\frac{6 !}{(6-4) ! 4 !}=\frac{6 !}{2 ! 4 !}=\frac{6 \times 5 \times 4 \times 3 \times 2 \times 1}{2 \times 1 \times 4 \times 3 \times 2 \times 1}=\frac{30}{2}=15$ Cara

Apakah langkah-langkah pekerjaan yang dilakukan Fina benar? Berikan alasan.

Adapun soal nomor 2 adalah soal yang telah dilengkapi oleh beberapa langkah penyelesaian dan siswa diminta untuk menentukan mana langkah mana yang benar atau salah dari setiap langkah yang ada pada penyelesaianya. Soal tersebut disertai dengan alasan mengapa bisa langkah tersebut dinyatakan benar atau salah, seperti yang terlihat pada Gambar 2.

Seorang peternak akan membeli hewan ternak untuk dipelihara. Dia akan membeli 2 ekor Sapi, 5 ekor Domba, dan 4 ekor Kambing. Seorang pedagang memiliki 5 ekor Sapi, 7 ekor Domba, dan 6 ekor Kambing. Berapa banyak cara yang dapat dilakukan untuk memilih hewan ternak yang akan dibeli adalah..

Gambar 2. Soal tes benar salah Permutasi

Penggunaan soal benar/salah bertujuan untuk mengetahui pemahaman konsep dalam penguasaan materi permutasi berdasarkan argumentasi yang diberikan siswa. Pengunaan 2 soal yang berbeda ini bertujuan untuk mengetahui seperti apa perbedaan siswa dalam menyelesaikan soal jika soal yang diberikan telah memiliki penyelesaian dan yang belum memiliki penyelesaian.

\section{Pola Argumentasi}

Ketiga siswa tersebut menjawab soal yang telah diberikan kemudian dilakan wawancara untuk mengetahui pola argumentasi yang digunakan siswa dalam menyelesaiakan soal dan 
perbedaan pola argumentasi siswa terhadap soal-soal yang memiliki bentuk yang berbeda seperti kedua soal yang diberikan. Kemudian hasil wawancara tersebut dianalisis mengunakan gabungan indikator pola argumentasi Toulmin dan pola argumentasi Mc. Neill \& Krajcik.

Pola Argumentasi Siswa Berkemamp;uan Matemaika Tinggi (SKT)

Pada jawaban soal nomor 1 yang SKT berikan menujukan bahwa SKT sudah cukup memhami konsep penyelesaian dalam kombinasi. Ini ditunjukan denga siswa SKT dapat menyelesaikan kombinasi Sapi, Domba dan Kambing. Meskipun SKT terdapat sedikit kekeliruan dalam memaknai fungsi faktorial. Ini bisa dilihat saat SKT mnguraikan 3! hasilnya $3 \times 1$ sedangkan hasil yg benar adalah $3 \times 2 \times 1$ sehingga hasil akhir kombinasi Sapi salah. Sedangkan saat menguraikan faktorial dipenyelesaian kombinasi untuk Kambing dan Domba SKT melakukan dengan benar sehingga hasil akhirnya benar, terlihat seperti pada gambar berikut ini:

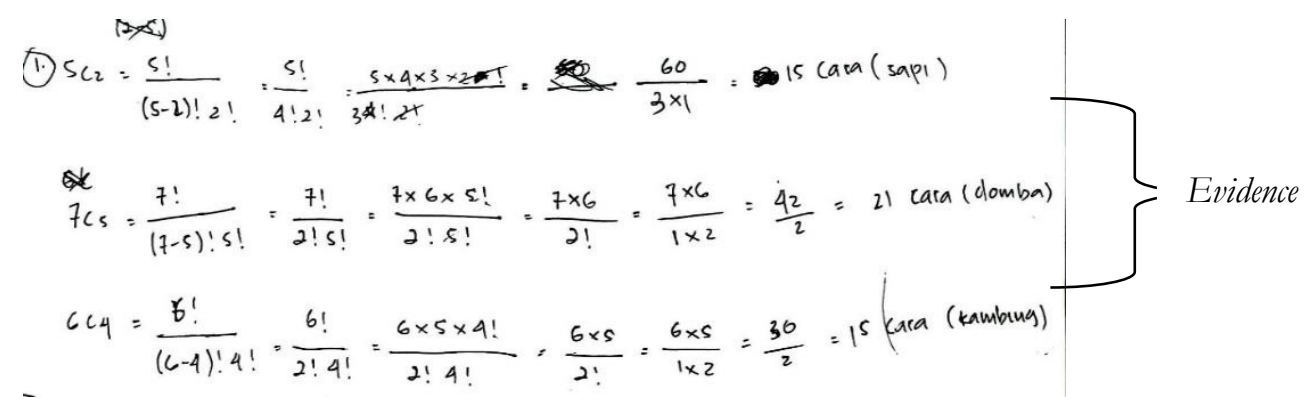

Berdasarkan jawaban tertulis pada soal nomor 1 dilakukan wawancara untuk mengetahui pola argumentasi yang digunakan siswa dalam menyelesaikan soal permutasi dan kombinasi. Adapun cuplikan hasil wawancaranya sebagai berikut: 
$\mathrm{P} \quad$ : Berdasarkan soal nomor 1 informasi apa saja yang anda dapatkan?

SKT : Seorang perternak yang akan membeli 5 ekor Domba, 2 ekor Sapi, dan 4 ekor

Kambing dari seorang pedagang yang memiliki 5 ekor Sapi, 7 ekor Domba, dan 6 ekor $\_$Data

Kambing.

P : Menurut anda apa yang hendak dicari di soal ini?

SKT : Berapa cara memilih Sapi, Domba, dan Kambing.

$\mathrm{P} \quad$ : Rumus apa yang digunakan untuk menyelesaikan soal ini dan apa yang mendasari anda mengunakan rumus ini?

SKT : Menggunakan rumus kombinasi, karena untuk menyelesaikannya menggunakan rumus ini.

$\mathrm{P} \quad$ : Jelaskan bagaimana tahapan-tahapan penyelesaian dari soal ini?

SKT : Cara memilih hewan Sapi yakni, ${ }^{5} \mathrm{C}_{2}$ dimasukan kedalam rumus kombinasi menjadi $\frac{5 !}{(5-2) ! 2 !}$ kemudian selesaikan yang ada di dalam kurung dengan dikurangi hasilnya menjadi $\frac{51}{3 ! 21}$, selanjutnya menjabarkan faktorial sehingga menjadi $\frac{5 \times 4 \times 3 \times 2 !}{3 ! 2 !}$, selanjutnya membagi dengan cara mencoret angka yang sama 2 ! sehingga hasilnya $\frac{5 \times 4 \times 3}{3 \times 1}$, selanjutnya mengalikannya sehingga hasilnya menjadi $\frac{60}{3}$, kemudian membagi antara 60 dengan 3 sehingga hasil 15 cara. Adapun cara untuk pemilihan Kambing dan Domba prosese tahapan penyelesaian sama dengan proses penyelesaian Sapi.

Dari hasil wawancara tersebut dapat dilihat bahwa SKT dapat menemukan informasi yang ada dalam soal dengan tepat, kemudian dapat menentukan apa yang di cari dari soal, kemudian dapat mejelaskan langkah-langkah penyelesaian dari soal ini, meskipun dalam penyelesaian kombinasi Sapi terdapat kekeliruan saat menguraikan 3! sehingga hasil yang didapatkan salah, sedangkan untuk penyelesaian kombinasi Domba dan Kambing hasil akhirnya yang didapatkan benar.

Adapun pada soal nomor 2 untuk mengetahui pola argumentasi SKT, berdasarkan hasil wawancara berikut ini: 
$\mathrm{P} \quad$ : Informasi apakah yang anda dapatkan dari soal nomor 2?

SKT: Proses pemilihan ketua kelas, wakil ketua, sekretaris, dan bendahara. Alvian dan Fina diminta untuk menghitung banyak cara untuk memilih ketua kelas, wakil ketua, sekretaris, dan bendahara dari 6 siswa yang tersedia.

$\mathrm{P} \quad$ : Menurut anda apa yang hendak di cari dari soal ini?

SKT: Banyak cara memilih ketua kelas, wakil ketua, sekretaris, dan bendahara

P : Rumus apa yang digunakan untuk soal ini dan apa yang mendasari anda untuk menggunakan rumus ini?

SKT: Menggunakan rumus kombinasi, karena cara untuk memilih ketua kelas, wakil ketua, sekretaris dan bendahara bisa menggunakan rumus kombinasi.

P : Menurut anda manakah penyelesaian yang benar atau salah dari penyelesaian yang dilakukan a yaitu Alvian atau yang b yaitu Fina, sertakan alasannya?

SKT: Untuk penyelesaian yang a adalah salah, karena langkah penyelesaian yang dilakukan Alvian salah dan dia tidak menggunakan rumus kombinasi sesuai dengan soal akan tetapi mengunakan rumus permutasi. Sedangkan untuk penyelesaian yang b jawabannya benar, karena penyelesaian yang dialakukan Fina sesuai yang diminta soal menggunakan rumus kombinasi.

Dari hasil wawancara pada soal ini dapat dilihat bahwa SKT mampu menentukan informasi yang terdapat di soal ini dengan tepat, namun SKT keliru saat menentukan apa yang dicari di soal ini, SKT juga keliru dalam menentukan rumus yang digunakan di soal ini, dan juga SKT salah saat menentukan mana penyelesaian yang benar atau salah yang dilakukan Alvian dan Fina.

Berdasarkan uraian diatas dapat diketahui bahwa pola argumentasi SKT dalam menyelesaikan soal permutasi dan kombinasi pada soal nomor 1 memenuhi 3 indiikator pola argumentasi yakni data, claim, dan evidence. Sedangkan pada soal nomor 2 SKT memenuhi 4 indikator pola argumentasi yakni data, claim, reasoning dan rebuttal. Pada soal nomor 1 dan 2 data yang diberikan oleh SKT berupa informasi yang terdapat di soal. Saat SKT diminta untuk mengungkapkan informasi yang ada pada soal. Saat wawancara SKT mengungkapkan informasi yang ada di soal apa adanya. Hal ini sejalan dengan hasil penelitian yang dilakukan oleh (Vendiagrys, 2015)bahwa siswa cenderung mengungkapkan informasi apa adanya dan persis yang tertulis di soal dalam bentuk kalimat yang sama.

Pada soal nomor 1 SKT memberikan data, claim yang tepat sehingga proses ini membantu SKT untuk mentukan evidence. Evidence yang SKT berikan sangat tepat. Ini dikarenakan SKT dapat menyelesaiakan kombinasi Kambing dan Domba dengan tahapantahapan penyelesaian dengan benar, sehingga hasil yang didapatkan benar.

Pada soal nomor 2 yaitu soal yang sudah terdapat penyelesaian ini SKT memberikan data dengan tepat, namun kemudian dia memberikan claim, reasoning dan rebuttal kurang tepat. Hal tersebut dikarenakan pada saat SKT diminta untuk menentukan mana penyelesaian yang benar yang dilakukan Alvian atau Fina, SKT menjawab dengan salah. Hal tersebut bisa terjadi dikarenakan lemahnya penalaran SKT dalam mengingat kembali materi permutasi yang telah diajarkan oleh gurunya. Hal ini sejalan dengan penelitian yang dilakukan oleh (Hartiana, 2014) 
bahwa lemahnya penalaran siswa untuk mengingat kembali meode-metode yang telah dipelajari sebelumnya dan menghubungkan fakta-fakta untuk dirangkai agar mampu menyelesaikan permasalahan selanjutnya.

\section{Pola Argumentasi Siswa Berkemampuan Matematika Sedang (SKS)}

Pada jawaban soal nomor 1 yang SKS berikan menujukan bahwa SKS kurang memahami konsep penyelesaian pada materi kombinasi. Meskipun demikian SKS juga sudah dapat menyelesaikan soal ini, meskipun dalam proses penyelesaiannya banyak kekeliruan seperti saat menyelesaikan kombinasi Sapi, SKS keliru saat membagi antara $\frac{5 \times 4 \times 3 \times 2 !}{3 ! 2 !}=\frac{5 \times 4 \times 3 !}{3 !}$, sehingga hasil akhirnya salah. Saat menyelesaikan kombinasi Kambing dan Domba SKS juga terdapat kekeliruan, sehingga hasil akhir yang didapatkan salah. Hal ini dapat dilihat dari gambar berikut ini:

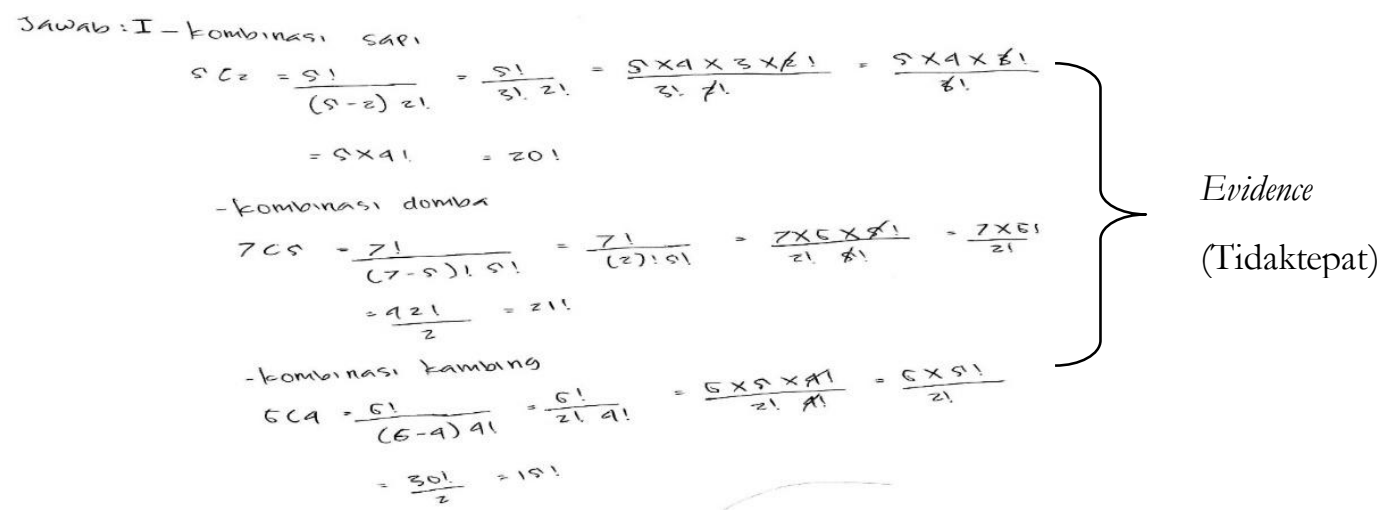

Berdasarkan jawaban tertulis SKS pada soal nomor 1 di atas dilakukan wawancara untuk menentukan pola argumentasi yang digunakan siswa dalam menyelesaikan soal permutasi dan kombinasi. Berikut adalah cuplikan wawancaranya:

$\mathrm{P} \quad$ : Berdasarkan soal nomor 1 informasi apa saja yang anda dapatkan?

SKS : Peternak yang akan membeli 2 ekor Sapi, 5 ekor Domba, dan 4 ekor Kambing dari seorang pedagang yang memiliki 5 ekor Sapi, 7 ekor Domba dan 6 ekor Kambing, yang ditanyakan adalah berapa banyak cara yang dapat dilakukan untuk memilih hewan ternak yang akan di beli.

$\mathrm{P} \quad$ : Apa yang hendak dicari dari soal ini?

SKS : Mencari kombinasi Kambing, Sapi, dan Domba.

$\mathrm{P} \quad$ : Rumus apa yang anda gunakan di soal ini dan apa yang mendasari anada untuk

SKS : Rumunakannya?
$\frac{n !}{(n-r) ! r !}$

Evidence (tidak tepat)

$\mathrm{P} \quad$ : Jelaskan bagaiman tahapan-tahapan penyelesaian soal ini? menjadi $\frac{5 \times 4 \times 3 \times 2 \text { ! }}{3 ! 2 !}$, selanjutnya membagi dengan cara mencoret 2 ! dan 3 ! yang sama menjadi $5 \times 4$ !, 
selanjutnya mengalikannya menjadi 20!. Adapun kombinasi Kambing dan Domba tahapan penyelesaiannya sama seperti kombinasi Sapi.

Dari hasil wawancara tersebut dapat dilihat bahwa siswa SKS dapat menentukan informasi yang terdapat di soal dengan tepat, kemudian SKS dapat menentukan apa yang dicari di soal ini, dan juga dia bisa menentukan rumus apa yang digunakan di soal ini dengan tepat. SKS juga dapat menjelaskan tahapan-tahapan penyelesaian dari soal ini, meskipun terdapat kekeliruan di tahapan penyelesaiannya sehingga hasil akhir yang didapatkan salah.

Adapun pada soal nomor 2 untuk mengetahui pola argumentasi SKS, berdasarkan hasil wawancara berikut ini:

P : Berdasarkan soal nomor 2 informasi apa yang anda dapatkan?

SKS : Alfian dan Fina melakukan pemilihan ketua kelas, wakil ketua, sekretaris, dan bendahara dari 6 siswa yang tersedia. Alfian dan Fina diminta untuk menghitung banyak cara memilih ketua kelas, wakil ketua, sekretaris, dan bendahara di kelasnya tersebut.

$\mathrm{P} \quad$ : Menurut anda apa yang hendak dicari di soal ini?

SKS : Banyak cara memilih ketua kelas, wakil ketua, sekretaris, dan bendahara.

$\mathrm{P} \quad$ : Rumus apa yang digunakan untuk soal ini dan apa yang mendasari anda menggunakan rumus ini?

SKS : Rumus permutasi, sesuai dengan soal.

$\mathrm{P} \quad$ : Menurut anda manakah penyelesaian yang benar atau salah dari penyelesaian yang dilakukan a yaitu Alvian dan b yaitu Fina, sertakan alasannya?

SKS : untuk penyelesaian di a adalah benar, karena Alvian menggunakan rumus permutasi dalam penyelesaiannya sesuai dengan pertanyaan soal, sedangkan untuk penyelesaian yang $b$ adalah salah, karena Fina menggunakan rumus kombinasi saat penyelesaiannya tidak sesuai dengan permintaan soal yang menggunakan rumus permutasi.

Dari hasil wawancara tersebut dapat dilihat bahwa SKS dapat menyelesaikan soal dengan tepat. SKS juga mampu menentukan informasi apa saja yang terdapat di soal dengan tepat, SKS juga mampu menentukan apa yang hendak dicari di soal dengan tepat, SKS dapat menentukan rumus apa yang digunakan di soal dengan tepat, kemudian SKS juga mampu menentukan mana penyelesaian yang dilakukan Alvian dan Fina benar atau salah dengan tepat, dan juga SKS dapat menjelaskan alsannya.

Berdasarkan urain diatas dapat diketahuwi bahwa pola argumentasi SKS pada soal nomor 1 memenuhi 3 indikator pola argumentasi yaitu data, claim, dan evidence. Sedangkan pada soal nomor 2 SKS memenuhi 4 indikator pola argumentasi yaitu data, claim, reasoning, dan rebuttal. Pada soal nomor 1 SKS meberikan data, dan claim engan tepat, sehingga mepermudah untuk memberi evidence. Evidence yang diberikan SKS kurang tepat, dikarenakan kurangnya penguasaan terhadap materi permutasi sehingga hasil yang didapatkan salah. Pada soal nomor 2 SKS memberikan data, claim, reasoning dan rebuttal dengan tepat, sehingga hasil yang di dapatkan benar sesuai dengan kunci jawaban. 
Pola Argumentasi Siswa Berkemampuan Matematika Rendah (SKR)

Pada jawaban soal nomor 1 yang SKR berikan menujukan bahwa SKR kurang memahami materi kombinasi, ini bisa dilihat bawah SKR tidak mengunakan rumus kombinasi saat penyelesaiannya tetapi menggunakan rumus permutasi dan juga SKR hanya dapat menyelesaikan soal sampai setengah saja, sehingga dia tidak menemukan hasil akhir dari penyelesaian kombinasi Sapi, Domba, dan Kambing.

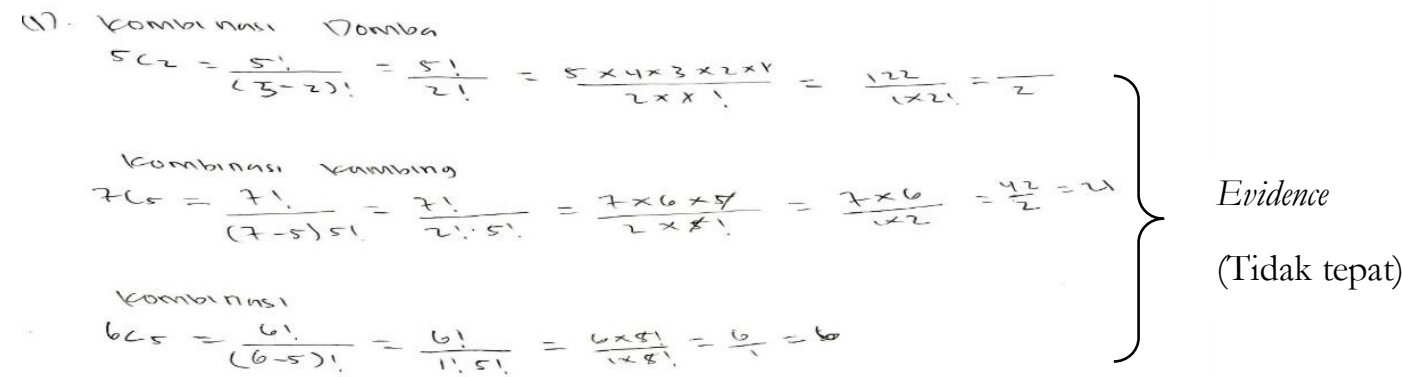

Berdasarkan jawaban tertulis yang dilakukan SKR pada soal nomor 1 di atas bahwa dilakukan wawancara untuk menentukan pola argumentasi dalam menyelesaikan soal ini. Berikut adalah cuplikan wawancaranya:

$\mathrm{P} \quad$ : Berdasarkan soal nomor 1 informasi apa saja yang anda dapatkan?

SKR : Seorang peternak yang akan membeli 2 ekor Sapi, 5 ekor Domba, dan 4 ekor Kambing. Sedangkan pedagang memiliki 5 ekor Sapi, 7 ekor Domba, dan 6 ekor Kambing.

$\mathrm{P} \quad$ : Apa yang hendak dicari dari soal ini?

SKR : Kombinasi Domba, Sapi, dan Kambing.

$\mathrm{P} \quad$ : Rumus apa yang digunakan di soal ini dan apa yang mendasari anda menggunakannya?

SKR : Rumus kombinasi, karena sesuai dengan soal.

$\mathrm{P} \quad$ : Jelaskan bagaimana tahapan-tahapan penyelesaian soal ini?

SKR : Kombinasi Domba, ${ }^{5} \mathrm{C}_{2}=\frac{5 !}{(5-2) !}=\frac{5 !}{2 !}=\frac{5 \times 4 \times 3 \times 2 \times 1}{2 \times 1 !} \frac{122}{1 \times 2 !}$. Kombinasi

Kambing ${ }^{7} C_{5} \frac{7 !}{(7-5) 5 !}=\frac{7 !}{2 ! 5 !}=\frac{7 \times 6 \times 5}{2 \times 5 !}=\frac{7 \times 6}{1 \times 2}=\frac{42}{2}=21$. Kombinasi Sapi ${ }^{6} \mathrm{C}_{5}=$ $\frac{6 !}{(6-5) !}=\frac{6 !}{1 ! 5 !}=\frac{6 \times 5 !}{1 \times 5 !}=\frac{6}{1}=6$.

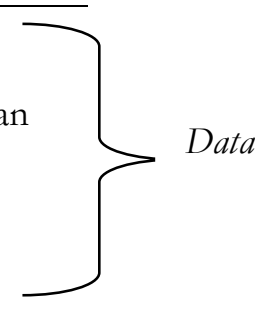

Dari hasil wawancara tersebut dapat dilihat bahwa siswa SKR mampu menentukan informasi apa saja yang ada di soal dengan tepat, kemudian dia mampu menentukan apa yang hendak dicari di soal dengan tepat, dan juga dia mampu menentuka rumus apa yang digunakan di soal dengan tepat, namu SKR tidak bisa menjelaskan tahapan-tahapan penyelesaian soal ini. 
Adapun pada soal nomor 2 untuk mengetahui pola argumentasi SKS, berdasarkan hasil wawancara berikut ini:

$\mathrm{P} \quad$ : Berdasarkan soal nomor 2 informasi apa saja yang anda dapatkan?

SKR: Pemilihan ketua kelas, wakil ketua

$\mathrm{P} \quad$ : Menurut anda apa yang hendak dicari dari soal ini?

SKR: Banya cara memilih ketua kelas, wakil ketua

P : Rumus apa yang digunakan di soal ini dan apa yang mendasari sehingga digunakan di soal ini?

SKR: Rumus permutasi, karena sesuai dengan soal.

P : Menurut anda manakah penyelesaian yang benar atau salah yang dilakukan di a yaitu Alvian dan di b yaitu Fina, sertakan alasannya?

SKR: Untuk penyelesaian di a adalah benar, karena caran kerja benar dan rumusnya benar.

Sedangkan untuk yang b adalah benar, karena cara kerjanya benar tetapi rumusnya salah.

Dari hasil wawancara tersebut dapat dilihat bahwa SKR tidak dapat menentukan Claim informasi di soal dengan lengkap, SKR tidak dapat menentukan apa yang hendak dicari di soal (Tidak ini dengan lengkap, dan juga dia dapat menentukan rumus yang digunakan di soal ini dengan tepat)

tepat, namu SKR keliru saat menentukan mana penyelesaian yang benar dan salah yang dilakukan Alfian dan Fina.

Berdasarkan uraian diatas dapat diketahui bahwa pola argumentasi SKR dalam Rebuttal menyelesaikan soal permutasi dan kombinasi. Pada soal nomor 1 SKR memenuhi 3 indikator pola argumentasi yaitu, data, claim, dan evidence. Sedangkan pada soal nomor 2 SKR memenuhi 4 indikator pola argumentasi yaitu, data, claim, reasoning dan rebuttal. Soal nomor 1 SKR dapat memberikan data dan claim dengan tepat, namun tidak dapat memberikan evidence dengan tepat, dikarnakan tahapan penyelesaian yang dilakukan SKR kurang tepat, sehingga hasil akhir tidak dapat ditemukan. Sedangkan pada soal nomor 2 SKR dapat menetukan data dengan tepat, sedangkan claim, dan reasoning yang dia berikan kurang tepat. Ini bisa di lihat saat SKR mebenarkan penyelesaian yang dilakukan Alvian dan Fina, seharusnya SKR menyalahkan penyelesaian yang dilakukan Fina dikarenakan rumus dan penyelesaian yang dilakukan salah. Pada saat SKR diminta untuk menjelaskan alsannya membenarkan keduanya, dia tidak dapat menberikan alasan dengan tepat. Hal ini disebabkan karena kurangnya kemampuan penalaran dan argumentasi SKR dalam menyelesaikan soal ini. Hal ini sejalan dengan penelitian yang dilakukan oleh (Lia Vendiagrys dan Iwan Junaedi, 2016) bahwa kurangnya kemampuan penalaran siswa sehingga siswa kurang mampu membangun kemampuan dalam berargumentasi berdasarkan kaidah dasar matematika. Adapun rebuttal yang diberikan SKR sangat tepat.

\section{Kesimpulan}

Berdasarkan hasil analisis dan pembahasan di atas, maka dapat diambil beberapa kesimpulan dari argumentasi yang telah diberikan siswa. Siswa yang memiliki kemampuan matematika tinggi memenuhi 3 indikator pola argumentasi dengan tepat yaitu, data, claim, dan 
evidence dalam proses pengerjaannya siswa menggunakan konsep-konsep dan pengetahuan yang telah didapatkan sebelumnya untuk menyelesaikan soal yang diberikan. Sedangkan siswa berkemampuan sedang dapat memenuhi 4 indikator pola argumentasi dengan tepat yaitu, data, claim, reasoning, dan rebuttal, dalam proses pengerjaannya siswa menggunakan konsep-konsep dan pengetahuan yang telah didapatkan sebelumnya untuk menyelesaikan soal yang diberikan. Adapun siswa yang memiliki kemampuan matematika rendah dapat memenuhi 3 indikator pola argumentasi dengan tepat yaitu, data, claim, dan rebuttal, namun dalam proses penyelesaian soal siswa tidak sepenuhnya menggunakan konsep-konsep dan pengetahuan yang dia miliki. Terkadang siswa mengunakan intuisi dalam menyelesaikan soal.

\section{Referensi}

Arifin Zainal, Penelitian Pendidikan Metode dan Peradikma baru. Cet. 1. Bandung: Remaja Rosdakarya, 2011.

Arikunto Suharsimi, Prosudur Penelitian: Suatu Pendekatan Peraktik. Cet. 13. Jakarta: Rineka Cipta, 2006.

Astuti Anggraini dan Leonard, "Peran Kemampuan komunikasi Matematika Terhadap Prestasi Belajar Matematika Siswa”, Jurnal Formatif, Vol. 2, Nomor 2, Fbruari 2012, hlm. 102110.

Aryan R. Bambang Soekisno, "Pembelajaran Berbasis Masalah Untuk Meningkatkan Kemampuan Argumentasi Matematis Mahasiswa", Jurnal Ilmiah Perogeram Setudi Matematika STKIP Siliwangi Bandung, Vol. 4, Nomor 2, September 2015, hlm. 120-139.

Budi Hermawan Santoso, "Peningkatan Aktifitas dan Hasil Belajar dengan Metode Probelem Basic Learning (PBL) pada Mata Pelajaran Tune Up Motor Bensin siswa kelas XI di SMK Insan Cendekia Turi Selatan", Jumal Taman Vokasi, Vol. 5, Nomor 1, Juli 2017, hlm. 40-45.

Christina Wenas Irene, Muhamad Rizal dan Linawati, "Penerapan Pendekatan Saintifik Unntuk Meningkatkan Pemahaman Siswa Klas XI MIA 5 pada Materi Permutasi dan Kombinasi di SMA Negeri 3 Palu", Jurnal Elekteronik Pendidikan Matematika Tadulako, Vol. 5, Nomor 3, Maret 2018, hlm. 304-315.

Dewi K. Ayu Indrawati dan Baiq Rika Ayu Febrilia, "Pola Argumentasi Siswa dalam Menyelesaikan Soal Sistem Persamaan Linear Tiga Variabel (SPLTV)", Jurnal Pendidikan Matematika, Vol. 5, Nomor 2, Desember 2019, hlm. 141-154.

Faesal Sanafiah, Metodologi Penelitian Pendidikan. Cet. 1. Surabaya: Usaha Nasional, 1982.

Handayani Putri, Murniati dan Sardianto,"Analisis Argumentasi Peserta Didik Kelas X SMA Muhamadiyah 1 Palembang dengan Menggunakan Model Argumentasi Toulmin”, Jurnal Inovasi dan Pembelajaran Fisika, Vol. 2, Nomor 1, Mei 2015, hlm. 60-68.

Hartiana, "Pengembangan Soal Pemecahan Masalah Berbasis Argumen Untuk Siswa kelas V Di SD Negeri 79 Palembang", Jurnal Pendidikan Matematika, Vol. 8, Nomor 2, 2014, hlm. 7685.

Junaini, M. Rusdi dan Muslim, "Penerapan Model Probelem Based Learning Untuk Meningkatkan Kemampuan Argumentasi Matematika Peserta Didik Klas X SMAN 2 Kota Jambi”, Jurnal Pendidikan Matematika, Vol. 4, Nomor 1, Fbruari 2020, hlm. 21-31. 
Khairani Nurul Abduh, Andoyo Sastromiharjo, dan Dadang S. Anshori, "Pola Argumentasi Pada Genre Teks Eksposisi Karangan Siswa SMA", Jurnal Babasa, Sastra, dan Pengerjaannya, Vol. 12, Nomor 1, Februari 2019, hlm. 71-84

Lexi J. Moleong, Metodologi Penelitian Kualitatif. Cet. 1. Bandung: Remaja Rosdakaraya, 2002. Mattew B. Miles, Qualitative and Analisis. Cet. 1. California: Sage Publication, 1994.

Mukhtar dan Erna Widodo, Konstruksi ke Arah Penelitian Deskriptif. Cet. 1. Yogyakarta: Auyrous, 2000.

Munir Rinaldi, Matematika Diskerit. Cet. 6. Bandung: Informatika Bandung, 2016.

Nasution, Metode Researh: Penelitian Ilmiah. Cet. 2. Jakarta: Bumiaksara, 1996.

Prihandoko, Pemahaman dan penyajian Konsep Matematika Secara Benar dan Menarik. Cet.1. Jakarta: Dediknas, 2006.

Putri Asih Jati Susilowati, "Profil Penalaran Siswa SMP Dalam Pemecahan Masalah Matematika Ditinjau Dari Perbedaan Gender", JRPM (Jurnal Review Pembelajaran Matematika), Vol. 1, Nomor 2, Desember 2016, hlm. 132-148.

Rifangi Kasmad, "Pembelajaran Matematika Kelas IV di Maderasah Ibtidaiyah Ma'arif Sendang Karangsari Pengasih kulon Progo Yogyakarta", Skripsi; PGMI Fakultas Ilmu Tarbiyah dan Keguruan UIN Sunan Kalijaga, 2010.

Rusmala, Heliawaty Hamrul, "Pembangunan Sistem Penjadwalan Kuliah Menggunakan Al Goritma Pewarnaan Graf', Jurnal Ilmiah d'Computar, Vol. 1, Juni 2011, hlm. 50-55.

Sugiyono, Metode Penelitian Ademiterasi. Cet. 9. Bandung: Alpabeta, 2002.

Sugiyono, Metode Penelitian Pendidikan: Pendekatan Kuantitatif-Kualitatif, dan Q\&D. Cet. 1. Bandung: Alfabeta, 2007.

Sukma Wahyu Ginanjar, Setiya Utari, dan Muslim, "Penerapan Model Argument-Driven Inquiry Dalam Pembelajaran IPA Untuk Meningkatkan Kemampuan Argumentasi Ilmiah Siswa SMP”, Jurnal Pengajaran MIPA, Vol. 20, Nomor 1, April 2015, hlm. 32-37.

Sumartini Tina Sri, "Peningkatan Kemampuan Penalaran Matematis Siswa Melalui Pembelajaran Berbasis Masalah", Jurnal Pendidikan Matematika, Vol. 5, Nomor 1, April 2015, hlm. 1-10.

Surakhmad Winarno, Pengantar Penelitian Ilmiah. Cet. 1. Bandung: Tarsito, 1984.

Syahid M. dan kurnia Noviartati, "Representasi Matematis Siswa Bergaya Kognitif Visualizer-Verbalizer dalam Menyelesaikan Soal Matematika TIMSS", Jurnal Gantang, Vol. 4, Nomor 1, April 2019, hlm. 49-59.

Syaodih Nana Sukmadinata, Metode Penelitian Pendidikan. Cet. 1. Bandung: PT. Remaja Rosdakarya, 2012.

Vendiagrys Lia dan Iwan Junaidi, “Analisis Kemampuan Pemecahan Masalah Matematika Soal Setipe TIMSS Berdasarkan Gaya Kogenitif Siswa Pada Pembelajaran Model Problem Based Learning”, Unnes Journal Of Mathematics Education Research, Vol. 4, Nomor. 1, Juni 2015, hlm. 3441.

Wulandari winda, Darmawijoyo dan Yusuf Hartono, "Pengaruh Pendekatan Permodelan Matematika Terhadap Kemampuan Argumentasi Siswa Klas VIII SMP Negeri 15 Palembang", Jurnal Pendidikan Matematika, Vol. 10, Nomor 1, Januari 2016, hlm. 115-126. 